\title{
Infestation of the Torrent Catfish (Siluriformes, Trichomycteridae) by an Exotic Crustacean (Copepoda, Lernaeidae) in Andean Mountains of Argentina
}

\author{
Luis Fernandez $^{1}$ (D), Eduardo Sanabria² ${ }^{\text {(D) }}$, Lorena Quiroga ${ }^{3}$ (i) \\ 'CONICET Tucuman, Fundacion Miguel Lillo, Tucumán, Argentina \\ ¿Universidad Nacional Cuyo, Facultad Ciencias Médicas, Mendoza, Argentina \\ ¿Universidad Nacional San Juan, Facultad de Ciencias Exactas, Físicas y Naturales, Departamento de Biología, San Juan, Argentina
}

ORCID IDs of the authors: L.F. 0000-0002-2605-3974; E.S. 0000-0003-3981-045X; L.Q. 0000-0002-0065-750X

Please cite this article as: Fernandez L, Sanabria E, Quiroga L. Infestation of the Torrent Catfish (Siluriformes, Trichomycteridae) by an Exotic Crustacean (Copepoda, Lernaeidae) in Andean Mountains of Argentina. Eur J Biol 2019; 78(1): 58-62.

\section{ABSTRACT}

Objective: This study reports the presence of a copepod, affecting adults of the torrent catfish in a tributary of the San Juan River in the southern part of South America.

Materials and methods: The fish (48.1-54.1 mm standard length) were collected in Los Bretes, San Juan province, Argentina. They were anesthetized, fixed in formalin, preserved in ethanol and deposited in the Ichthyological Collection of the FACEN.

Results: Three torrent catfish (Trichomycterus corduvensis) examined were infested with nine copepod parasites (Lernaea cyprinacea), which were attached to the gill, urogenital opening, and base pectoral fin.

Conclusion: According to our results, this is the first record of parasitism of Lernaea on the torrent catfish (T. corduvensis) and a new locality from the Andean Mountains of Argentina.

Keywords: Anchor worm invasion, Lernaea cyprinacea, torrent catfish, Trichomycterus corduvensis, andes

\section{INTRODUCTION}

Lernaea cyprinacea Linnaeus 1758 or anchor worm is a common parasite and appears almost all over the world in freshwater fish (1). Lernaea is an ectoparasitic copepod causing lernaeosis in several species of fishes. In South America, the reports of lernaeosis are scarce, and it should be remembered that there are thousands of native freshwater fish on this continent that have never been examined for parasites (2-5). Argentina is one of the most diverse countries in the world and little is known about the diversity of invertebrate species of ichthyoparasites of inland aquatic ecosystems (6). Lernaeids comprise of a family of Copepoda (100+ species) in which the small free-living adult females become parasitic after copulation, metamorphose, and grow to a relatively large size without molting (7). These ectoparasitic copepods are distributed naturally in Africa, Central Asia, Southern of Siberia, and are reported in Europe, Japan, and Israel (7). In Argentina, the first record of lernaeid parasites infecting freshwater fish is from 1993, parasitizing Odontesthes bonariensis in Córdoba $(4,8)$. The torrent catfish Trichomycterus corduvensis is widely distributed in tropical South America and occurring in a remarkable variety of environments such as temporary streams, subterranean drainages in caves, high elevations, fossorial sandy setting, and warm thermal waters (9). Trichomycterus corduvensis feed on benthic aquatic macroinvertebrates, such as dipteran larvae, coleopterans, ephemeropterans, trichopterans, plecopterans, and crustaceans and it is distributed in the western part of Argentina, including thermal waters and high elevations $(9,10)$. Species of Trichomycteridae (Figure 1) have never been reported with infestation by lernaeids, being this study and the first report in San Juan province (Figures 2A-B). 


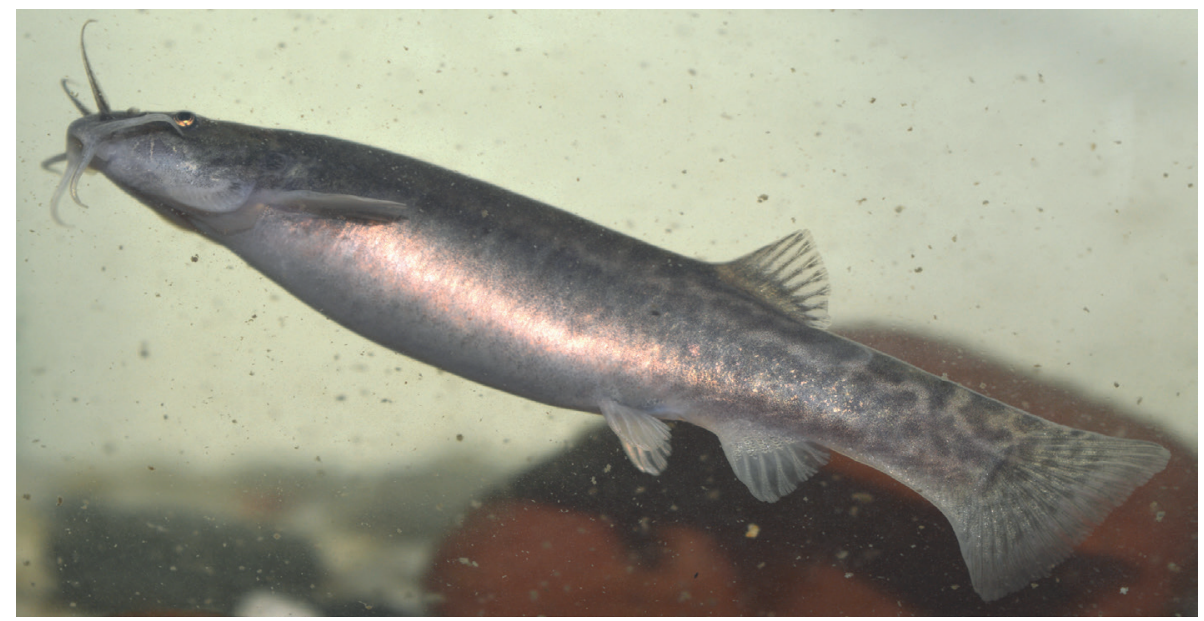

Figure 1. Trichomycterus corduvensis widely distributed in Argentina.

Table 1. Specimens of Trichomycterus corduvensis (FACEN 61) infested by Lernaea cyprinacea.

\section{$\mathrm{n}=3$ (in $\mathrm{mm} \mathrm{SL})$}

48.1

54.1

48.1

Abbreviations: standard length (SL), gill (g), urogenital opening (u), pectoral-fin base (p).

\section{Parasites number and area}

$3 \mathrm{p}$ (right) (Fig. 3B), 1 p (left), $2 \mathrm{~g}$ (right)

$1 \mathrm{u}$ (Fig. 3C)

$2 \mathrm{~g}$ (left) (Fig. 3A)
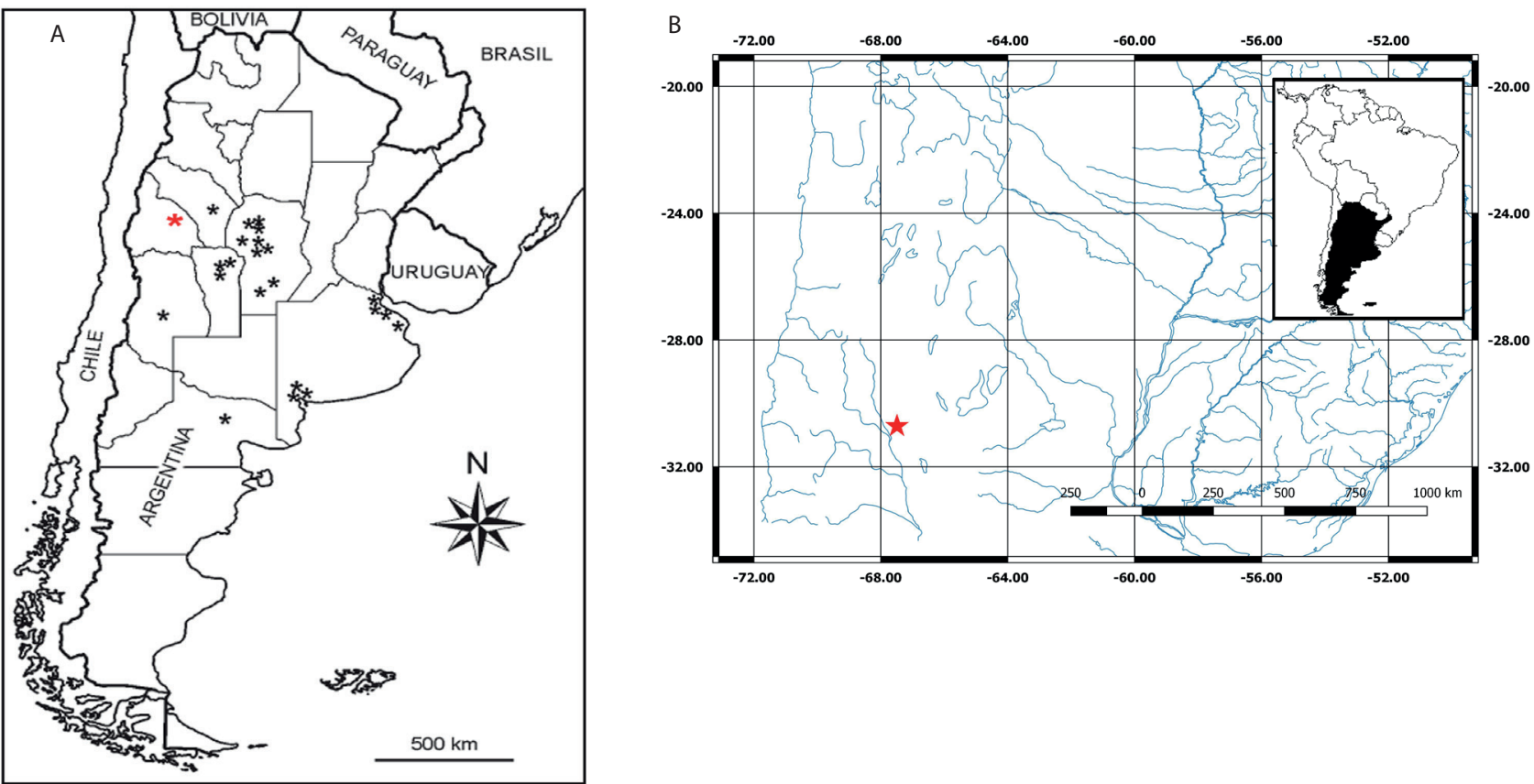

Figure 2. A. Map of Lernaea cyprinacea modified from Waicheim et al 2017. B. The new record (red asterisk) is at 1,011 $\mathrm{m}$ above sea level in Los Bretes, San Juan. 


\section{MATERIAL AND METHODS}

The fish were collected in San Juan province, Argentina $\left(67^{\circ} 29^{\prime} 35^{\prime \prime} \mathrm{W}, 30^{\circ} 42^{\prime} 54^{\prime \prime} \mathrm{S}\right.$, at 1,011 m elevations) in December 2005 (Figure 2B). Specimens were kept alive and later anesthetized and killed with ice in situ. They were fixed in $10 \%$ formalin, preserved in $70 \%$ ethanol and deposited in the Ichthyological Collection of the Facultad Ciencias Exactas y Naturales, Universidad Nacional de Catamarca, Argentina (FACEN): FACEN 61, 3 specimens, 48.1-54.1 mm Standard Length (SL), Los Bretes, Departamento Valle Fértil, Provincia San Juan, Argenti- na. The taxonomic identification was based on Gervasonii et al. (8), Moreno et al. (11), and Fuentes Parra (12).

\section{RESULTS AND DISCUSSION}

Three torrent catfish showed severe physical damage by the adult parasites of Lernaea cyprinacea. They were found macroscopically on various parts of the host's body of Trichomycterus corduvensis (Figures 3A-C, Table 1). Nine parasites were attached in: the gill (4 parasites), urogenital aberture (1 parasite), and the base of the pectoral fin (4 parasites). Although Lernaea cyprinacea seem to
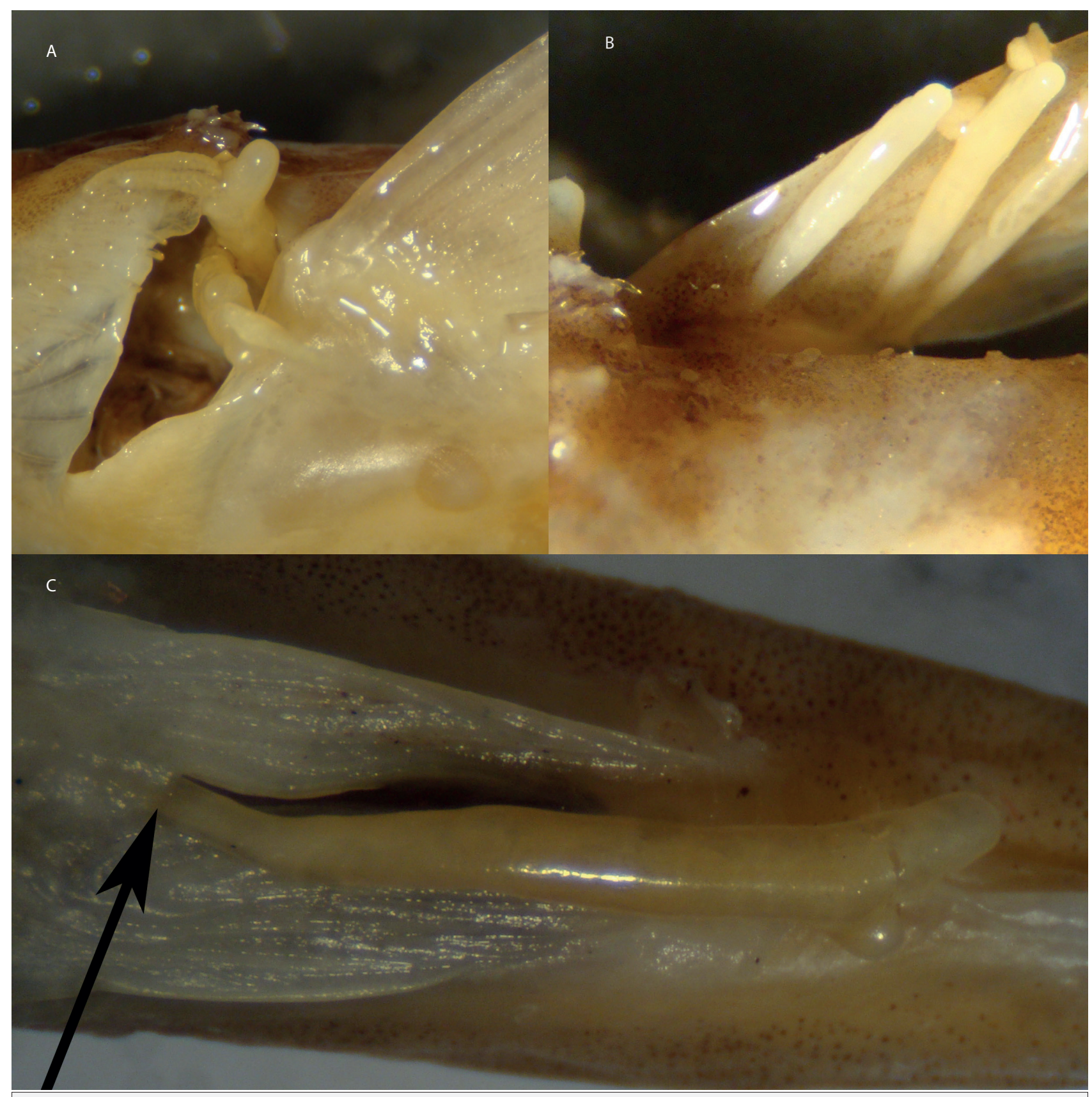

Figure 3. Trichomycterus corduvensis infected with Lernaea cyprinacea. FACEN 61: Argentina, Provincia de San Juan, Departamento Valle Fértil, Los Bretes, $48.1 \mathrm{~mm} \mathrm{SL:} \mathrm{A.} \mathrm{gill} \mathrm{(2)} \mathrm{and} \mathrm{B.} \mathrm{pectoral} \mathrm{fin} \mathrm{base} \mathrm{(3);} 54.1 \mathrm{~mm} \mathrm{SL:} \mathrm{C.} \mathrm{urogenital} \mathrm{opening} \mathrm{(1).}$ 
attach themselves to random parts of the host's body, Bulow et al. (13) and Stavrescu-Bedivan et al. (14) found that L. cyprinacea preferred sheltered areas on the fins and skin for attachment. One of the hypotheses proposed to explain this copepod attachment preference is that fins offer greater protection against currents and tissues at the base of the fins may be more easily penetrated (14-16). We agree with that (4 specimens) and we add the gill (4 specimens) and urogenital opening (Table 1 and Figures $3 A-C$ ) as sites of preference.

Plaul et al. (5) and Gervasoni et al. (8) summarized in Tables 1 and 2 the localities of L. cyprinacea in Argentina (Buenos Aires, Corrientes, Córdoba, Mendoza, Río Negro, San Luis, La Rioja, and Santa Fé) and mentioned as hosts of fish species: Siluriformes: Corydoraspaleatus, Hypostomussp, Rhamdiasapo; Characiformes: Astyanax bimaculatus, A. eigenmanniorum, A. hermosus, Astyanax $\mathrm{sp}$, Bryconamericus iheringii, Cheirodon interruptus, Oligosarcus jenynsii, Prochilodus lineatus, Cyphocharax voga; Cypriniformes: Carassius auratus, Cyprinus carpio, Botia macracantha; Atheriniformes: Odontesthes bonariensis; Cyprinodontiformes: Jenynsia sp, Poecilia sp, Xiphophorus helleri; Salmoniformes: Oncorhynchus mykiss; Perciformes: Percichthys trucha.

The life cycle of this parasite does not include an intermediate host and it has nine stages in its life cycle, including three free-living naupliar stages, five copepodites stages and one adult stage $(12,17,18)$. After male and female adults mate on the fish host $\left(23-24{ }^{\circ} \mathrm{C}\right.$ temperature) after which males die ( 24 hs after), females metamorphose, insert their cephalic region with 4 lateral processes into the host tissue and then produce two conspicuous egg sacs (18-20). In the Los Brete of San Juan, Cyprinus carpio is absent and thus other fish species are spreading this copepod upstream.

According to Plaul et al. (5), Piasecki et al. (21), the existence of the parasite and its pathogenic activity in very austral locality demonstrates an increase in temperature generated by contamination. Plaul et al. (5) mentioned that the extreme conditions facilitate the proliferation of the parasites, such as concentration of salts by natural eutrophication or irrigation agriculture. Climatic changes could also increase significantly the geographical dissemination of L. cyprinacea in high altitude. L. cyprinacea has spread to different parts of the Argentina via movement of aquaculture, such as Odontesthes bonariensis. For example Soares et al. (18), Mancini et al. (22), and Bethular et al. (23) mentioned that the silverside (O. bonariensis) has been introduced into numerous freshwater environments in Argentina such as other countries (e.g, Japan, Italia, Perú, Bolivia, Uruguay and Chile). Whether accidental or deliberate, the introduction of exotic species is one of the major reasons for the loss of biological diversity, habitat alteration, and overexploitation of natural resources $(8,24-26)$. This opportunistic ectoparasite is extremely harmful and can be transmitted by water source causing infestation in the Andean basin where others endemic catfishes live (27-29). Parasitological studies are needed to determine the current status of L. cyprinacea, especially in the northwestern of Argentina. This new report demonstrates the absence of host specificity and the high adaptability to numerous habitats of freshwater, including polluted streams or endorheic systems in high elevation. For this reason, the provincial and municipal commissions on the environment must promote strong policies directed to prevention of disease in protected areas and the conservation of Andean catfish endangered by exotic fish and its parasitic infestations.

Peer-review: Externally peer-reviewed.

Author Contributions: Conception/Design of study: L.F., E.S., L.Q.; Data Acquisition: L.F., E.S., L.Q.; Data Analysis/Interpretation: L.F., E.S., L.Q.; Final Approval and Accountability: L.F., E.S., L.Q.; Drafting Manuscript: L.F., E.S., L.Q.; Critical Revision of Manuscript: L.F., E.S., L.Q.; Technical or Material Support: L.F., E.S., L.Q.; Supervision: L.F., E.S., L.Q..

Acknowledgement: We thanks to Facultad Ciencias Exactas Naturales, Universidad Nacional Catamarca (FACEN-UNCA) and Instituto Biodiversidad Neotropical (IBN-UNT) by facilities and other assistances. For the loan of specimens we thank to J. Andreoli Bize (FACEN).

Conflict of Interest: The author has no conflict of interest to declare.

Financial Disclosure: PIP (Proyecto Investigación Plurianual CONICET) Project no 11420090100321

\section{REFERENCES}

1. Urku C, Onalan S. First report of Lernaea cyprinacea (Copepoda: Lernaeidae) on rainbow trout (Onchorhynchus mykiss) from the Sari Mehmet Dam Lake in Van-Turkey. Eur J Biol 2018; 77 (1): 42-5. https://doi.org/10.26650/EuroJBiol.2018.398174

2. Thatcher VE. Perulernaea pirapitingae n. sp. (Copepoda: Lernaeidae) a parasite of the serrasalmid fish, Piaractus brachypomus from the Meta River, Colombia. Amazoniana 2000; 16: 249-57.

3. Barroso de Magalhaes A. First record de Lernaeosis in native fish species form a natural environment in Minas Gerais state, Brazil. Pan-Am J Aquat Sci 2006; 1: 8-10.

4. Mancini M, Rodríguez C, Ortiz M, Salinas V, Tanzola R. Lerneosis en peces silvestres y cultivados del centro de Argentina. Biol Acuat 2008; 24: 33-41.

5. Plaul SE, García Romero N, Barbeito CG. Distribution of the exotic parasite, Lernaea cyprinacea (Copepoda, Lernaeidae) in Argentina. Bull Eur Assoc Fish Pathol 2010; 30 (2): 65-73.

6. Chemes SB, Takemoto RM. Diversity of parasites from Middle Paraná system freshwater fishes, Argentina. Int J Biodivers Conserv 2011; 3 (7): 249-66.

7. Thatcher VE, Willians EH. Comparative morphology of three native lernaeids (Copepoda: Cyclopoida) from Amazonian fishes and descriptions of two new genera. J Aquat Anim Health 1998; 10: 300-8.

8. Gervasoni, SH, Chemes SB, Scaglione MC, Cerutti RD. First report of Lernaea cyprinacea (Crustacea: Lernaeidae) parasiting Rhamdia quelen (Pisces: Heptapteridae) in Santa Fe (Argentina) under hatchery conditions. Rev Colomb Cienc Pec 2018; 31 (3): 229-34. https://doi.org/10.17533/udea.rccp.v31n3a08 
9. Fernandez L. Family Trichomycteridae Pencil catfishes, torrent catfishes, and parasitic catfishes (candirús). Van Der Sleen P, Albert JS, editors. Field Guide to the Fishes of the Amazon, Orinoco, and Guianas. Princeton University Press, Nueva Jersey; 2017. p 311-22.

10. Fernandez L, Vari RP. New species of Trichomycterus (Teleostei: Siluriformes) from the Andean Cordillera of Argentina and the second record of the genus in thermal waters. Copeia 2012; 2012: 631-6. https://doi.org/10.1643/Cl-12-035

11. Moreno O, Granado C, García Novo F. Variabilidad morfológica de Lernaea cyprinacea (Crustacea: Copepoda) en el embalse de Arrocampo (Cuenca del Tajo: Caceres). Limnetica 1986; 2: 265-70.

12. Fuentes Parra, AN Presencia de Lernaea cyprinacea en peces de ornato de acuarios en la Comarca Lagunera. Universidad Autónoma Agraria Antonio Narro Unidad Laguna División Regional de Ciencias Animal, PhD thesis. 2008.

13. Bulow FJ, Wimmingham JR, Hooper RC. Occurrence of the copepod parasite Lernaea cyrpinacea in a stream fish population. Trans Am Fish Soc 1979; 108: 100-2.

14. Stavrescu-Bedivan MM, Popa OP, Popa LO, Infestation of Lernaea cyprinacea (Copepoda: Lernaeidae) in two invasive fish species in Romania, Lepomis gibbosus and Pseudorasbora parva. Knowl Manag Aquat Ecosyst 2014; 414: 12. https://doi.org/10.1051/ kmae/2014024

15. Gutierrez-Galindo JF, Lacasa-Millan MI. Population dynamics of Lernaea cyrpinacea (Crustacea: Copepoda) on four cyprinid species. Dis Aquat Org 2005; 67: 111-4.

16. Iqbal Z, Shafqat A, Haroon F. Lernaea diversity and infection in Indian and Chinese carps under semi-intensive culture conditions in Lahore. Punjab J Animal Plant Sci. 2012; 22: 923-6.

17. Hoffman GL. Parasites of North American freshwater fishes. 2nd ed. New York: Cornell University Press 1999.

18. Soares IA, Salinas C, del Ponti O, Mancini MA, Luque JL First molecular data for Lernaea cyprinacea (Copepoda: Cyclopoida) infesting Odontesthes bonariensis, a commercially important freshwater fish in Argentina. Rev Bras Parasitol Vet 2018; 27 (1): 106-9. https://doi. org/10.1590/S1984-29612018005

19. Nagasawa K, Inoue A, Myrat S, Umino T. New host records for Lernaea cyprinacea (Copepoda), a parasitic of freshwater fishes, with a checklist of the Lernaeidae in Japan (1915-2007). J Grad Sch Biosp Sci 2007; 46: 21-33.

20. Waicheim MA, Blasetti G, Cordero P, Rauque CA, Vioszzi GP. The invasive copepod Lernaea cyprinacea Linnaeus, 1758 (Copepoda, Cyclopoidea, Lernaeidae): first record for Neuquén River, Patagonia, Argentina. Check List 2017; 13 (6): 997-1001. https://doi. org/10.15560/13.6.997.

21. Piasecki W, Goodwin A, Eiras J, Nowak B. Importance of Copepoda in freshwater Aquaculture. Zool Stud 2004; 43 (2): 193-205.

22. Mancini M, Bucco C, Salinas V, Larriestra A, Tanzola R, Guagliardo. Seasonal variation of parasitis in Pejerrey Odontesthes bonariensis (Atheriniformes, Atherinopsidae) from La Viña Reservoir (Córdoba, Argentina). Rev Bras Parasitol Vet 2008; 17: 28-32.

23. Bethular A, Mancini M, Salinas V, Echañiz S, Vignati A, Larriestra A. Alimentación, condición corporal y principales parásitos del Pejerrey (Odontesthes bonariensis) del embalse San Roque (Argentina). Biología Acuática 2014; 30: 59-68.

24. Tanzola RD, Semenas L, Viozzi G. Manejo y estado actual del conocimiento de los parásitos de peces cultivados en Argentina. Tavares-Dias M, editors. Manejo e Sanidade de Peixes em Cultivo. Embrapa Amapá, Macapá; 2009. p 3438-468.

25. Bednarska M, Bednarski M, Soltysiak Z, Polechoriski R. Invasion of Lernaea cyrpinacea in rainbow trout (Onchorhynchus mykiss). Acta Sci Pol 2009; 8: 27-32.
26. Berry CR, Babey GJ, Shrader T. Effect of Lernaea cyprinacea (Crustacea: Copepoda) on stocked rainbow trout (Onchorynchus mykiss). J Widelife Dis 1991; 27: 206-13. https://doi.org/10.7589/0090-355827.2.206

27. Fernandez L, Andreoli Bize J. Trichomycterus alterus (Marini, Nichols \& La Monte, 1933) and T. corduvensis Weyenberg 1877 (Siluriformes: Trichomycteridae): new records from the High Andean Plateau. Check List Journal of biodiversity data 2017; 13, 2068. ISSN 1809-127X. https://doi.org/10.15560/13.2.2068

28. Fernandez L, Andreoli Bize J. New species of Trichomycterus (Siluriformes: Trichomycteridae) from the High Andean Plateau of Argentina. Zootaxa 2018; 4504 (3): 359-70. https://doi.org/10.11646/ zootaxa.4504.3.3

29. Fernandez L, Sanabria EA, Quiroga LB, Vari RP. A new species of Silvinichthys (Siluriformes, Trichomycteridae) lacking pelvic fins from mid-elevation localities of the southern Andes, with comments on the genus. J Fish Biol 2014; 84 (2): 372-82. https://doi.org/10.1111/ jfb.12291 